\title{
Entre riscos e ameaças: independência e controle do Tribunal de Contas da União na Assembleia Constituinte de 1988
}

Thiago do Nascimento Fonseca ${ }^{1}$ (D)

\begin{abstract}
Por que atores políticos correriam o risco de ser controlados no futuro por instituições independentes de combate à corrupção? $\mathrm{O}$ artigo pretende explicar o que motiva políticos a conferir maior independência e poder a essas instituições, sob o risco de serem controlados no futuro. Por meio do método process tracing, o artigo sistematiza evidências quanto à aprovação do desenho institucional do Tribunal de Contas da União no Processo Constituinte de 1988. Os resultados indicam que, independentemente das preferências dos políticos, instituições de combate à corrupção conquistam maior poder por meio de ameaças à sobrevivência política dos atores em contextos de incerteza futura. O diagnóstico questiona se instituições independentes de combate à corrupção são o produto de disputas democráticas, visto que nem sempre são resultado direto da preferência majoritária de representantes eleitos.
\end{abstract}

Palavras-chave: instituições de combate à corrupção; accountability horizontal; independência institucional, judicial review; corrupção

\section{Introdução}

O Tribunal de Contas da União (TCU) exerce um papel importante no controle à corrupção no sistema político brasileiro. A mesma instituição concentra as prerrogativas de fiscalizar, julgar e - se for pertinente ao caso - impor sanções administrativas a quaisquer agentes, públicos e privados, que participem da administração, direta e indireta, de bens e valores públicos federais, independentemente do nível da federação em que esses recursos são geridos ${ }^{2}$. Devido à concentração da arrecadação tributária no nível federal e à elevada quantidade de recursos transferidos aos níveis subnacionais (Arretche, 2010), atualmente são mais de 12 mil unidades administrativas jurisdicionadas pelo TCU no país.

\footnotetext{
1 Programa de Pós-Graduação em Ciência Política. Universidade de São Paulo (USP). São Paulo (SP), Brasil. E-mail: <thiago.nascimento.fonseca@usp.br>.

2 Também é importante ressaltar que o papel do TCU não se restringe ao combate à corrupção, dado que a função do controle externo também envolve o auxílio à gestão pública na identificação de ineficiências.
} 
O desenho institucional do órgão criou oportunidades de controle sobre as instituições representativas, não apenas devido à sua ampla jurisdição e ao seu rol de atribuições, como também em virtude de suas garantias de independência e de sua autonomia institucional. Os ministros do TCU contam com garantias de vitaliciedade e inamovibilidade do cargo, seu método de seleção é dissociado do ciclo eleitoral e pouco dependente do Poder Executivo ${ }^{3}$, características que, segundo a literatura especializada, protegeriam o órgão de pressões políticas (Santiso, 2007; Speck, 2011). A instituição também tem autonomia para escolher as unidades administrativas a serem fiscalizadas, enquanto as fiscalizações compulsórias solicitadas pelo Congresso Nacional ocupam uma pequena fatia dos trabalhos do Tribunal (Fonseca, 2019).

No entanto, por que atores políticos correriam o risco de ser controlados no futuro por instituições protegidas por regras de independência? Por que representantes eleitos pelas urnas criariam dificuldades para manter sua influência sobre instituições de combate à corrupção? A importância dessas indagações não se restringe aos estudos sobre a adoção de modelos institucionais de controle financeiro. Também existe um conjunto de trabalhos que se deparam com as mesmas questões ao investigar a adoção de judicial review.

O presente artigo pretende explicar o que motivou os constituintes a aprovar um modelo institucional de controle financeiro capaz de oferecer riscos futuros aos representantes eleitos. As evidências oferecem uma nova hipótese explicativa para a adoção de instituições de combate à corrupção com regras de independência, sem desvalidar teses já levantadas pela literatura. Embora atores políticos possam manifestar preferência por fortalecer as atribuições e por conferir garantias de independência às instituições de controle 4 para limitar seus adversários no futuro - como argumentam os especialistas da adoção de judicial review (Chavez, 2004; Finkel, 2008; Ginsburg, 2003; Knight, 2001; Magaloni, 2008; Ramseyer, 1994; Stephenson, 2003) -, os resultados do presente artigo também indicam que instituições de combate à corrupção são fortalecidas por meio de ameaças à sobrevivência dos atores políticos em contextos de incerteza futura.

No caso do TCU, constituintes provenientes da situação governista do regime militar buscaram ampliar as atribuições e o rol de jurisdicionados do TCU, bem como atribuir independência e autonomia à instituição, que naquele momento era quase que exclusivamente composta por ministros escolhidos pela Arena. Por outro lado, apesar de

\footnotetext{
3 Um terço dos ministros é escolhido pelo presidente da República, sujeito à aprovação do Senado, sendo dois alternadamente dentre auditores e membros do Ministério Público junto ao Tribunal, indicados em lista tríplice pelo TCU, segundo os critérios de antiguidade e merecimento. Os dois terços restantes são escolhidos pelo Congresso Nacional. O Tribunal de Contas também conta com ministros substitutos, provenientes dos quadros técnicos da própria instituição, que não agem apenas em caso de vacância dos demais ministros. Também são requisitos necessários para o cargo: ser brasileiro com mais de 35 e menos de 65 anos de idade; possuir idoneidade moral e reputação ilibada, notórios conhecimentos jurídicos, contábeis, econômicos e financeiros ou de administração pública; e ter mais de dez anos de exercício profissional na área.

${ }^{4}$ Neste artigo, instituições de controle se referem às instituições que exercem prerrogativas de controle sobre as ações de representantes eleitos, tais como tribunais de contas, cortes constitucionais, controladorias e procuradorias. Embora o objetivo do artigo seja o de explicar exclusivamente o desenho institucional do TCU, o conteúdo da pesquisa também oferece achados que podem dar luz ao exame de outras instituições de controle.
} 
preservarem a autonomia do órgão de controle e fortalecerem suas atribuições, líderes da oposição ao regime militar (PMDB) almejaram proteger a soberania do Congresso Nacional, diminuindo o rol de jurisdicionados e as oportunidades para aplicação de sanções administrativas, bem como abolindo a independência do Tribunal de Contas. No final do Processo Constituinte, as lideranças dos maiores partidos, inclusive aqueles que buscaram limitar o poder institucional do Tribunal, somaram esforços para mobilizar suas bancadas com o objetivo de garantir autonomia e independência ao órgão após os ministros do TCU anunciarem uma ampla operação de fiscalização, que poderia atingir todos os políticos que participaram da gestão de recursos públicos durante o mandato anterior. Em meio ao contexto delicado de incerteza futura, próprio da transição democrática, os líderes dos maiores partidos cederam aos interesses do Tribunal de Contas para não correrem o risco de ser atingidos pela operação.

Na próxima seção, "Delegação de soberania?", trabalhos sobre a evolução de instituições de combate à corrupção e a adoção da judicial review serão revisados, destacando os incentivos dos atores envolvidos no processo. Na terceira seção, "Método, arcabouço conceitual e fontes empíricas", será discutido como o método process tracing é capaz de elucidar o poder explicativo das hipóteses por meio de evidências qualitativas empiricamente observáveis. Na quarta, "O desenho do TCU definido pela Constituinte de 1987-1988", a análise do processo decisório será explorada destacando as evidências empíricas que sustentam a hipótese. Por fim, em "Discussão", o argumento central será retomado, bem como as implicações teóricas provenientes dos resultados.

\section{Delegação de soberania?}

Após a promulgação da Constituição Federal de 1988, as instituições de combate à corrupção no Brasil continuaram a sofrer um processo gradual de fortalecimento institucional, apesar de persistirem problemas de coordenação entre os órgãos de controle (Filgueiras, 2018; Taylor e Buranelli, 2007). Essas mudanças não podem ser atribuídas exclusivamente ao cálculo estratégico dos representantes eleitos, dado que os próprios controladores buscaram fortalecer suas corporações (Arantes e Moreira, 2017; Arantes, 2002 , 2011). No que se refere às instituições públicas de auditoria, auditores se engajaram em iniciativas para aprimorar a capacidade técnica do Tribunal de Contas da União, adaptando-se às mudanças legais introduzidas pela Lei de Responsabilidade Fiscal (Loureiro, Teixeira e Morais, 2009), enquanto membros da Controladoria Geral da União (CGU) buscaram se relacionar com grupos organizados da sociedade civil e outros órgãos de controle (Loureiro et al., 2012).

O engajamento dos controladores no destino de suas corporações não é um fenômeno restrito às instituições públicas de auditoria. O desenvolvimento de instituições do sistema de justiça também foi marcado pela busca de interesses corporativos de juízes, promotores e profissionais do direito (Arantes e Moreira, 2017; Arantes, 2002, 2011, 2015; 
Koerner e Freitas, 2013). Tal quadro ressalta a importância de estratégias metodológicas que incluam na análise não apenas as preferências e o comportamento dos atores políticos, mas também as estratégias empreendidas pelos próprios agentes burocráticos, que buscam aumentar seu poder institucional.

Apesar de instituições de combate à corrupção não serem imutáveis no tempo, não se deve perder de vista que os principais dispositivos que deram forma ao modelo institucional do TCU - o qual continua vigente - tiveram que ser aprovados especificamente durante o Processo Constituinte de $1988^{5}$. A Constituição de 1967, aprovada no regime militar, já conferia ao órgão autonomia para a condução de auditorias e vitaliciedade aos seus ministros, embora estes fossem escolhidos exclusivamente pelo presidente da República com aprovação pelo Congresso (Teixeira e Alves, 2011). Entretanto, como se tornará evidente adiante, os constituintes discutiram por completo o desenho institucional do Tribunal. Por isso, ainda resta compreender o que motivou os constituintes a aprovar regras que visavam conferir autonomia e independência ao Tribunal de Contas, além de aumentar suas prerrogativas e seu rol de jurisdicionados, criando oportunidades para serem controlados no futuro por atores não eleitos. Afinal, embora o ativismo dos controladores seja um elemento importante para compreender o fortalecimento das instituições de combate à corrupção após 1988, dispositivos constitucionais não podem ser aprovados sem o consentimento de representantes eleitos.

A centralização do controle interno na CGU em 2003 ressalta ainda mais o problema teórico tratado neste artigo. O governo federal buscou fortalecer esse órgão e, em certa medida, concedeu discricionariedade para a CGU exercer seu papel de controle. No entanto, o presidente da República diminuiu o risco futuro de ser onerado pelos controladores, dado que manteve em suas mãos a prerrogativa de escolher e de demitir o ministro encarregado de dirigir o órgão de controle. Além disso, o governo tem influência sobre a composição da Controladoria, visto que seu quadro de pessoal tem considerável participação de funcionários de confiança ${ }^{6}$. Inclusive, a centralização do controle interno pode ser interpretada como um recurso à disposição do Executivo federal para controlar a burocracia e membros da coalizão no Legislativo (Olivieri, 2010). Mesmo após o reconhecimento público e acadêmico da atuação eficiente do órgão, os técnicos da CGU permaneceram sob o comando de ministro indicado politicamente. Se o Executivo federal reluta em conferir garantias de independência à CGU, por que os constituintes concederam vitaliciedade e inamovibilidade aos ministros do TCU?

A literatura sobre a adoção de judicial review também é útil para orientar estudos sobre a adoção de instituições de combate à corrupção com garantias de independência,

\footnotetext{
5 Inclusive, especialistas identificam que desde 1891 mudanças institucionais bruscas sofridas pelo TCU acompanharam transições de regime político (Speck, 2000; Teixeira, 2010; Teixeira e Alves, 2011).

6 Apesar de contar com baixo percentual de funcionários formalmente vinculados aos partidos políticos quando comparada às demais instituições públicas federais (Schlosser-Bersch, Taylor e Praça, 2017). Em 2015, por exemplo, $21,2 \%$ do quadro de pessoal da CGU era composto por funcionários que ocupavam cargos de confiança.
} 
como ocorreu com o TCU durante a transição democrática no Brasil. Ambas as instituições envolvem dilemas muito semelhantes quanto à delegação de independência e autonomia. Embora a Constituição seja a fonte dos critérios utilizados para o exercício da judicial review, enquanto instituições públicas de auditoria controlam recursos públicos por meio de normas constitucionais e infraconstitucionais mais limitadas, em ambos os casos regras de independência e atribuições de controle são aprovadas por atores políticos sob o risco de serem controlados futuramente.

Quatro problemas teóricos sobre a adoção de regras de independência merecem destaque. O primeiro se refere à incerteza futura da competição eleitoral. Em democracias competitivas, governos seriam motivados a adotar cortes constitucionais independentes em momentos de baixas expectativas quanto ao seu sucesso nas próximas eleições, ora com a finalidade de criar uma nova instância para enfrentar ações do próximo governo (Chavez, 2004; Ginsburg, 2003; Knight, 2001; Ramseyer, 1994; Stephenson, 2003), ora para preservar suas preferências por meio de magistrados com valores e preferências semelhantes (Finkel, 2008; Magaloni, 2008)7. Por ocorrer no período de transição democrática, a Constituinte brasileira de 1988 trouxe incertezas a respeito de quais forças ocupariam os governos seguintes, incentivando conflitos em torno da configuração que as instituições de controle tomariam.

O segundo problema teórico diz respeito à existência prévia e ao ativismo de instituições de controle que buscam manter ou aumentar seu poder político. Enquanto grande parte da literatura restringiu sua análise ao cálculo estratégico dos atores políticos (Chavez, 2004; Finkel, 2008; Ginsburg, 2003; Knight, 2001; Magaloni, 2008; Ramseyer, 1994; Stephenson, 2003), Hirschl (2004) ressaltou o protagonismo de grupos jurídicos e elites econômicas, que buscariam transferir o controle constitucional para as cortes, a fim de limitar o poder de representantes eleitos. Essa questão ganha ainda mais relevo quando são considerados os momentos críticos nos quais atores políticos podem reavaliar o papel das cortes constitucionais. Em perspectiva semelhante, Koerner e Freitas (2013) argumentam que, no Processo Constituinte de 1988, ministros do Supremo Tribunal Federal se beneficiaram de sua própria posição institucional para influenciar o Processo Constituinte, mantendo seu papel de controle constitucional. Veremos adiante que os ministros do TCU se comportaram de modo semelhante ao buscar apoio de partidos oriundos da Arena e, principalmente, ao ameaçar a reputação dos constituintes com uma grande operação de fiscalização em um momento de incerteza futura.

O terceiro problema teórico se refere à relevância do contexto para a adoção do controle constitucional. Apesar de fatores contextuais não serem os únicos com poder de influência, é inegável que atores políticos incluem em seu cálculo estratégico os dilemas

\footnotetext{
7 Ainda não há consenso quanto aos indicadores mais adequados para a incerteza eleitoral. Enquanto Ginsburg e Versteeg (2014) empregam a diferença de cadeiras entre o primeiro e o segundo partido mais votado antes e após a aprovação da nova Constituição, Chavez (2004) e Ginsburg (2003) utilizam como indicador a fragmentação partidária.
} 
de seu tempo. A onda de reconstrução após a Segunda Guerra Mundial, o cenário de independência de ex-colônias, a transição para regimes democráticos, a reintrodução de economia de mercado em países de passado comunista e a incorporação de normas internacionais e supranacionais formariam os diferentes contextos em que atribuições de controle são delegadas às instituições independentes (Elster, 1995; Hirschl, 2004; Shapiro, 2002). O contexto do Processo Constituinte de 1988 abriu oportunidades para que grupos burocráticos buscassem manter e ampliar seu poder político, visto que a Carta Constitucional foi elaborada em um processo decisório inicialmente descentralizado, que favorecia a inserção de diversas demandas na agenda (Gomes, 2006). Não apenas instituições jurídicas, como o STF e o Ministério Público, reivindicaram seus interesses corporativos (Arantes e Moreira, 2017; Arantes, 2002, 2011, 2015; Koerner e Freitas, 2013), como também os ministros do TCU se empenharam em ampliar suas atribuições e garantir regras que visassem assegurar autonomia e independência.

O último problema teórico diz respeito aos diferentes modelos institucionais de controle. Afinal, atores políticos se deparam somente com o dilema de manter ou descartar as instituições de controle independentes ou, alternativamente, avaliam se aprovam ou rejeitam um modelo específico de controle em detrimento de outros? Embora estudos sobre a adoção de judicial review enfatizem a existência de uma ampla variedade de modelos de controle constitucional, geralmente não investigam como essa diversidade afeta o cálculo dos atores (Ginsburg e Versteeg, 2014; Hirschl, 2004; Shapiro, 2002; Sweet, 2000). Ginsburg e Versteeg (2014), por exemplo, restringiram sua análise a processos constituintes nos quais atores políticos poderiam institucionalizar o controle constitucional pela primeira vez, omitindo momentos em que novas disputas remodelaram seu desenho institucional. Poucos estudos superaram essa limitação ao incluir como variável dependente diferentes modelos institucionais. Ginsburg (2003) identificou que partidos fortes tenderiam a constitucionalizar cortes constitucionais com fácil acesso, mandatos longos e maior número de assentos, enquanto Knight (2001) indicou que o escopo e a participação no controle constitucional dependeriam da expectativa dos atores políticos quanto à composição futura do Judiciário e do Legislativo.

Veremos adiante que no Brasil praticamente todos os constituintes concordaram em manter o Tribunal de Contas da União, mas os grandes dilemas a respeito da aprovação de dispositivos específicos envolviam o trade-off entre aumentar o poder de controle do órgão e preservar a soberania do Congresso Nacional. A maior parte dos constituintes preferiu aumentar o rol de prerrogativas do TCU e permitir que o órgão exercesse atividades de controle por iniciativa própria, mas majoritariamente não concordou em aprovar regras que visassem assegurar independência e autonomia de modo ilimitado. Entretanto, garantias de independência e autonomia foram aprovadas no final do processo, após o Tribunal de Contas ameaçar os constituintes com amplo programa de fiscalização, a Operação Transparência. 


\section{Método, arcabouço conceitual e fontes empíricas}

Para explicar o desenho institucional do Tribunal de Contas da União acordado na Constituinte de 1988, o presente artigo utiliza o método process tracing. O método fornece explicações a partir da identificação de mecanismos que sustentam nexos causais entre o resultado e fatores explicativos (Beach e Pedersen, 2013a, 2013b). Uma das grandes vantagens de seu emprego é a sistematização das evidências empíricas que sustentam a presença dos mecanismos causais, permitindo que o leitor avalie a qualidade das evidências com transparência.

Van Evera (1997) propôs quatro testes úteis para avaliar o poder das evidências para desvalidar hipóteses (certainty) e para confirmar hipóteses (uniqueness). O primeiro teste, straw-in-the-wind, envolve evidências não conclusivas que fortalecem a rejeição de hipóteses. O segundo, hoop test, emprega evidências também não conclusivas, mas que aumentam a certeza de uma hipótese. Os discursos dos constituintes, por exemplo, são evidências que fortalecem os interesses em jogo, mas não fornecem respostas conclusivas referentes ao resultado final do jogo político. O terceiro, smoking gun, faz uso de evidências conclusivas para desvalidar hipóteses, mas não para sustentar uma hipótese específica. Iniciativas provenientes dos próprios apoiadores do TCU na Constituinte no sentido de diminuir o rol de jurisdicionados do órgão e de estabelecer limites às suas sanções são evidências conclusivas contra o argumento de que partidos teriam o interesse de instituir um forte sistema de controle contra si mesmos. Por fim, o doubly decisive test envolve evidências conclusivas para confirmar uma hipótese específica. $O$ fato de que as lideranças mudaram de posicionamento e infringiram o regimento interno ao encaminhar duas vezes à votação em Plenário a emenda pela adoção da vitaliciedade dos ministros do TCU, aprovando essa regra, seria uma evidência conclusiva para a hipótese de que a ameaça por meio da Operação Transparência surtiu efeito na adoção desse importante dispositivo de independência. Assim como na tradição qualitativa, a qual orienta a construção da explicação a partir do resultado (Mahoney e Goertz, 2006), essa estratégia analítica parte do desenho institucional do TCU acordado no final do Processo Constituinte de 1988 para verificar as ações e preocupações enfrentadas pelos atores políticos e burocráticos envolvidos. O desenho institucional do Tribunal é composto por regras qualitativamente diferentes que regulam suas atividades e relações com as instituições representativas. Naquele momento, o que estava em jogo não era apenas manter ou substituir o Tribunal de Contas, mas envolvia as normas que definiriam o poder de influência do órgão de controle sobre a política e a gestão de recursos públicos.

Para sistematizar como os diversos atores tentaram incidir sobre seu desenho institucional, os dispositivos constitucionais em disputa foram classificados em quatro dimensões. A primeira se refere às atribuições de controle, que podem abarcar funções de fiscalização, julgamento e imposição de sanções. A segunda diz respeito à jurisdição sobre a qual o TCU exerce suas prerrogativas. A jurisdição envolve diferentes níveis de governo 
e atores - políticos, burocráticos e privados -, bem como objetos de natureza desigual, como contratos, despesas fixas, recursos humanos, transferências constitucionais e convênios. A terceira dimensão, a autonomia, remete às regras que conferem ao Tribunal discricionariedade quanto a quais atribuições e sobre quais jurisdicionados deseja priorizar seus esforços. Por fim, a independência institucional envolve garantias contra pressões de instituições representativas durante o desempenho de suas funções de controle, tais como vitaliciedade e inamovibilidade do cargo, o processo de seleção de seus dirigentes, além de independência financeira. As regras do desenho institucional nem sempre abarcam uma única dimensão. Hipoteticamente, se atores políticos diminuírem a jurisdição do órgão, simultaneamente estarão diminuindo sua autonomia ao limitar o leque de opções sobre as quais o TCU pode exercer suas atribuições. Em outro exemplo, na ausência de garantias de independência contra interferências políticas sobre o exercício cotidiano de suas funções, o Tribunal de Contas pode antecipar suas ações, restringindo sua própria autonomia, priorizando fiscalizações sobre atores de posição hierárquica mais baixa. De qualquer forma, a análise que será oferecida adiante indicará como diferentes atores buscam restringir ou aumentar cada uma dessas dimensões com o objetivo de preservar a soberania do Congresso Nacional ou conferir poder político ao TCU.

Não existe consenso sobre a diferença entre os conceitos autonomia e independência institucional. Contudo, os conceitos utilizados neste artigo são úteis para diferenciar regras que asseguram o direito de definir prioridades (autonomia) dos dispositivos que impõem custos aos atores políticos que desejam influenciar a qualidade dos trabalhos desempenhados pela instituição (independência). Nesse sentido, possuir discricionariedade para escolher quais jurisdicionados devem ser auditados estaria vinculado à autonomia institucional, ao passo que conferir vitaliciedade ao corpo dirigente do órgão a fim de romper vínculos partidários do passado seria um exemplo de independência.

A independência institucional analisada neste artigo, sobretudo, refere-se às regras que impõem custos contra a influência política sobre o Tribunal de Contas. O objetivo aqui não é estimar o impacto real de regras de independência (de jure) sobre o desempenho cotidiano da instituição (de facto), como especialistas buscaram investigar (Fonseca, 2019; Hidalgo, Canello e Lima-de-Oliveira, 2016; Melo, Figueiredo e Pereira, 2009). Uma das regras mais importantes para a independência do Tribunal, por exemplo, diz respeito à vitaliciedade dos ministros, porque esse dispositivo gera elevados custos aos atores políticos que almejam pressionar o órgão. Afinal, com a vitaliciedade, o presidente da República perde a prerrogativa de afastar os dirigentes da instituição. É possível que esse dispositivo não proteja o TCU por completo contra a influência política, mas é pouco plausível supor que na ausência dessa regra os custos de intervenção política seriam os mesmos. Como se tornará evidente a seguir, não é por acaso que a vitaliciedade gerou um grande embate entre os ministros do Tribunal e os constituintes. Contudo, outros dispositivos de independência ressaltados pela literatura também serão abordados, como 
o método de seleção pouco dependente do chefe do Executivo (Santiso, 2007; Speck, 2011).

Os resultados do artigo foram atingidos a partir de cinco principais fontes. Em primeiro lugar, foram analisadas as estratégias adotadas pelos ministros do TCU e seus vínculos partidários do passado por meio de informações biográficas e atas da Constituinte. Em segundo, as regras dos regimentos internos foram revisadas para identificar como o poder decisório esteve distribuído de modo desigual entre os atores. Em terceiro, os debates constituintes foram examinados a fim de observar as preferências e os principais dilemas enfrentados pelos constituintes. Em quarto, os anteprojetos e projetos de todas as fases do processo foram comparados um a um para observar as alterações que ocorreram a cada etapa, bem como as votações das emendas aprovadas. Por último, jornais da época foram pesquisados.

\section{O desenho do TCU definido pela Constituinte de 1987-1988}

Nesta seção, serão apresentadas as evidências que sustentam o argumento central do artigo. As forças políticas que defendiam a substituição do Tribunal de Contas da União por outro modelo de controle de contas eram praticamente inexpressivas. Os membros dos maiores partidos concordaram em manter o TCU no quadro institucional brasileiro com o argumento frequente de que a experiência do órgão proporcionaria um controle de contas mais eficiente. Entretanto, isso não significa que não houve disputas em torno do desenho institucional do Tribunal de Contas. Os constituintes divergiam quanto aos dispositivos que preservavam a soberania do Congresso Nacional ou conferiam maior poder político ao TCU.

A Figura 1 ilustra as disputas em torno do desenho institucional do TCU durante o Processo Constituinte. Para fortalecer a instituição, os ministros do Tribunal buscaram o apoio de líderes partidários vinculados ao governo militar. Considerando que os ministros do TCU foram majoritariamente indicados pelo governo autoritário, líderes do PFL e do PDS defenderam a expansão da independência, da autonomia e das atribuições do órgão de controle, ao passo que líderes do PMDB buscaram limitar o poder institucional do Tribunal de Contas, o que evitaria o risco de serem controlados no futuro. Mesmo após a alteração do regimento interno da Constituinte - que limitou a força institucional de relatores de esquerda, transferindo poder decisório para a maioria no Plenário - , o PMDB ainda possuía a maioria das cadeiras. No entanto, no contexto delicado da transição democrática, que conferia incerteza à sobrevivência política dos constituintes, o TCU anunciou a Operação Transparência, ameaçando fiscalizar todos os atores políticos que participaram da última gestão. Com isso, além de o Plenário expandir as atribuições e a autonomia do TCU, as lideranças de esquerda do PMDB, que até então buscaram limitar o poder institucional do TCU nas comissões, abandonaram suas preferências iniciais e mobilizaram suas bancadas para aprovar a vitaliciedade dos ministros, mesmo contrariando regras do regimento interno. 
Figura 1

\section{Disputas referentes ao desenho institucional do TCU na Assembleia Nacional Constituinte de 1988}

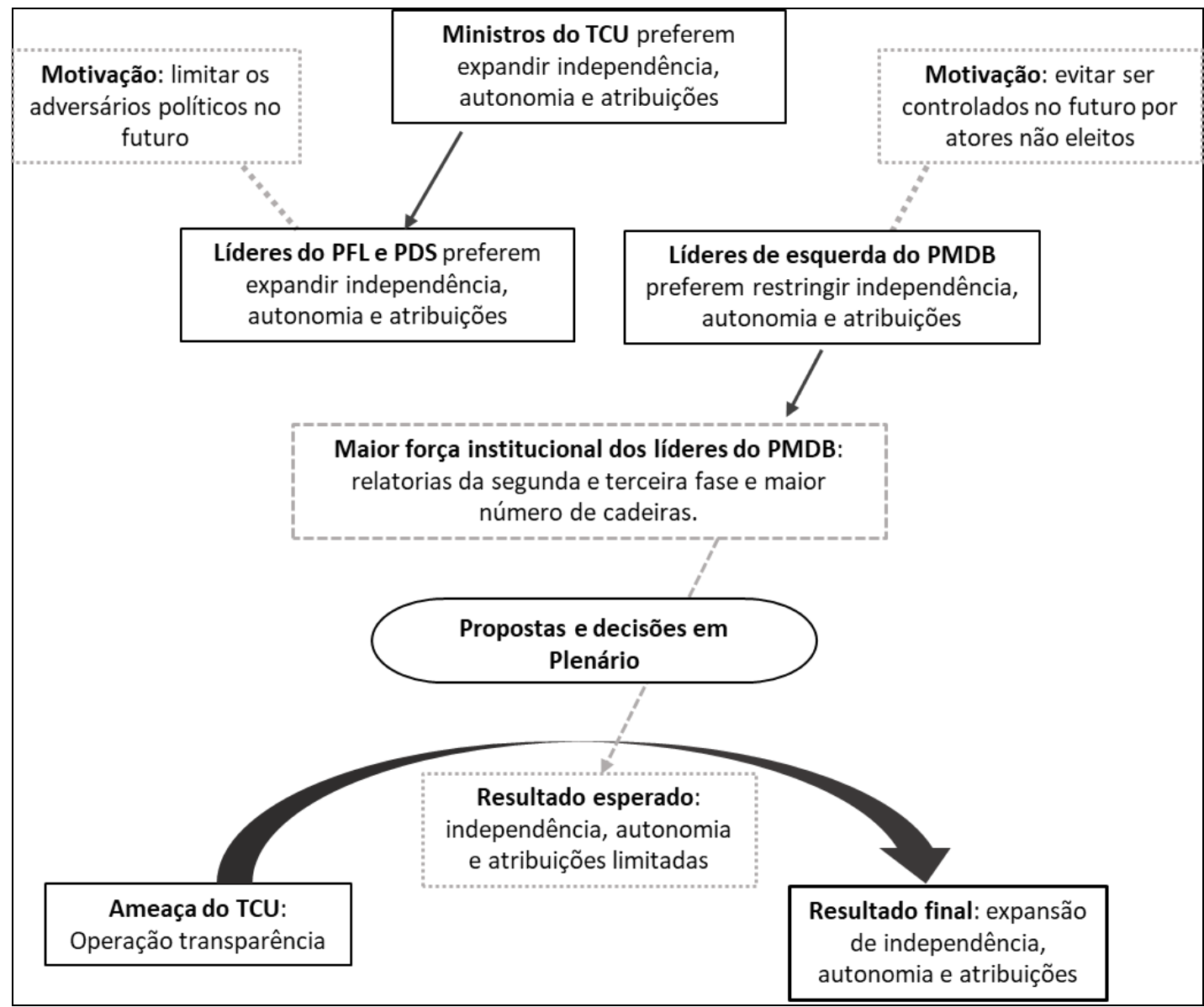

Fonte: Elaborada pelo autor.

Regras do processo e distribuição desigual de poder

O Processo Constituinte foi dividido em quatro fases. Sob as regras do primeiro regimento interno, os cargos de relatoria concentravam maior poder decisório em relação às maiorias. O ocupante do posto de relator nas subcomissões e comissões temáticas seria responsável por aprovar ou rejeitar, inteira ou parcialmente, as emendas propostas pelos constituintes. Em seguida, as emendas aprovadas e as rejeitadas pelo relator seriam votadas em bloco em sua respectiva subcomissão ou comissão temática ${ }^{8}$.

Antes de começarem os trabalhos, a composição dos postos de relatoria e presidência de todas as subcomissões e comissões já estava definida pelo que ficou

\footnotetext{
8 Brasil (1987b).
} 
conhecido como o "Grande Acordo" (Gomes, 2006). Portanto, atores políticos e grupos de interesse que atuaram na Constituinte já estavam cientes das opções para conquistar apoio necessário às suas demandas. No caso dos Tribunais de Contas, a primeira fase do processo, na Subcomissão do Orçamento e Fiscalização Financeira, foi dirigida por lideranças provenientes da Arena, ligadas à situação governista do regime militar, enquanto a segunda fase, na Comissão Temática e Comissão de Sistematização, foi dirigida por forças de esquerda do PMDB.

Ao perceber que as regras regimentais e a distribuição de relatorias concentravam muito poder decisório em lideranças de esquerda do PMDB, durante os trabalhos da Constituinte a maioria se uniu para alterar o regimento interno (Gomes, 2006), diminuindo o poder do relator na terceira fase do processo, na Comissão de Sistematização ${ }^{9}$. Na última fase, constituintes poderiam propor destaques para a votação por maioria absoluta em plenário, desde que inicialmente apoiados por 187 (33,5\%) constituintes no mínimo, o que conferia poder de agenda à minoria e de deliberação à maioria ${ }^{10}$.

\section{Composição do TCU durante a Constituinte}

Mesmo sabendo que os dispositivos constitucionais poderiam ser facilmente alterados por relatores de esquerda nas comissões subsequentes, os ministros do Tribunal de Contas da União pretenderam influenciar o processo desde a primeira etapa, buscando o apoio de lideranças do PDS e do PFL, devido à sua proximidade política com exintegrantes da Arena. Em vez de buscarem o apoio de lideranças de esquerda do PMDB, que ocupariam as relatorias seguintes, os ministros do TCU conquistaram o apoio de atores como o constituinte Messias Góis (PFL), que os convidou para debater as propostas.

Durante o Processo Constituinte, o Tribunal de Contas da União era comporto por nove ministros, cuja maioria possuía vínculos próximos à situação governista do regime militar. Cinco deles, inclusive o presidente do TCU, haviam sido deputados federais pela Arena e ocupado importantes cargos no Congresso ou nesse partido ${ }^{11}$. Dois ministros estavam inseridos em carreiras burocráticas em instituições sujeitas às intervenções do governo, mais especificamente, o Banco do Brasil e o próprio TCU ${ }^{12}$. A única exceção foi o ministro Thales de Albuquerque Ramalho, ex-deputado federal pelo MDB (Brasil, 2008).

A próxima seção mostra que, segundo os ministros do TCU, suas propostas estavam de comum acordo com os demais tribunais de contas subnacionais ${ }^{13}$. Entretanto,

\footnotetext{
9 Antes da mudança do regimento, o relator poderia rejeitar ou aprovar emendas oriundas das fases anteriores, mas sem alterar o sentido original de seu conteúdo.

10 Brasil (1988b).

${ }^{11}$ Os cinco ministros antigos filiados são Fernando Gonçalves (presidente do TCU durante a Constituinte), Luciano Brandão Alves de Souza, Alberto Hoffmann, Adhemar Paladini Ghisi e Jorge Vargas.

12 Ewald Sizenando Pinheiro, antes de tomar posse como ministro do Tribunal, fez sua carreira burocrática na própria instituição, que durante o regime militar estava sujeita a intervenções do governo federal. Mário Pacini, por sua vez, ocupou altos cargos no Banco do Brasil antes da nomeação como ministro.

13 Brasil (1987a, p. 127-128).
} 
apesar de se proferirem como representantes de todos os tribunais de contas, as discussões e as preocupações dos constituintes levantadas durante os debates envolveram mais o controle externo sobre recursos públicos federais do que o relacionado aos recursos dos demais níveis de governo. Provavelmente a preocupação dos constituintes de priorizar o nível federal incentivou os ministros do TCU a aproveitar a ocasião para dar maior atenção às suas preocupações particulares.

\section{Estratégias adotadas na Subcomissão}

A Subcomissão do Orçamento e Fiscalização Financeira foi presidida por João Alves (PFL) e contou com a atuação do relator José Luiz Maia (PDS), ambos de partidos sucessores da Arena. Segundo o regimento interno, o relator elaboraria um anteprojeto a partir de emendas propostas individualmente por parlamentares. Caberia ao relator aceitar ou rejeitar as emendas e, em seguida, encaminhar à votação em bloco. Se não fosse aprovado o anteprojeto, a comissão seguinte, dirigida por lideranças de esquerda do PMDB, decidiria sobre o assunto.

Os ministros do TCU se apresentaram como representantes de todos os tribunais de contas, federal e subnacionais, e fizeram um discurso conciliador, com propostas que aparentemente não colidiam com o interesse da maioria dos constituintes. Segundo os ministros, o Congresso deveria retomar o controle e o poder decisório, suprimidos durante o regime militar ${ }^{14}$. O Tribunal de Contas, sobretudo, deveria estar integrado ao Congresso Nacional, conferindo-Ihe o embasamento técnico que Ihe faltava. Argumentaram, inclusive, que não tinham a intenção de opinar sobre questões políticas, concentrando sua atenção sobre o diagnóstico dos problemas correntes do sistema de fiscalização financeira e as soluções possíveis de ser empreendidas. O princípio sustentado era o da eficiência. Segundo o ministro presidente Fernando Gonçalves:

Precisamos, efetivamente, de uma integração do trabalho eficiente do Tribunal de Contas com o trabalho eficiente do Congresso Nacional... O Tribunal está umbilicalmente ligado ao Poder Legislativo, para oferecer a sua colaboração. Fizemos um julgamento técnico, V. Ex. fazem um julgamento público, um julgamento político. Temos, então, de dar embasamento técnico como a mim faltou, no tempo em que fui Deputado, para poder exercer com eficiência e eficácia o mandato que, honrosamente, V. Ex. possuem (...) [E que] resulte a Constituição com que o povo sonha e que irá refletir a cultura, o pensamento mais amplo do Constituinte eleito, que, sem dúvida alguma, represente a vontade do povo brasileiro (...) O Tribunal de Contas quer estar ligado, umbilicalmente, ao Poder Legislativo, sobretudo nesta hora, em que a

\footnotetext{
${ }^{14}$ Não apenas nas discussões sobre o sistema de fiscalização financeira, mas em quase todos os debates da Assembleia Nacional Constituinte, o tema da soberania do Congresso era evidente.
} 
Constituinte está em marcha, para a glória e o conceito cada vez maior do País, no concerto das Nações (Brasil, 1987a, 3a Reunião, p. 140).

Contudo, as propostas dos ministros que foram endereçadas aos constituintes não acompanharam por completo o seu discurso. Embora se pronunciassem como representantes dos tribunais subnacionais, as demandas estavam mais ligadas aos problemas institucionais do plano federal ${ }^{15}$. O Quadro 1 apresenta o resumo das propostas, sem alterar o sentido integral da exposição do ministro Alberto Hoffmann, classificando-as segundo as dimensões de atribuição (separadas por tipo), jurisdição, autonomia e independência. Uma mesma proposta pode se relacionar com mais de uma dimensão. As atribuições de fiscalização, por exemplo, sempre acompanham uma jurisdição específica.

\footnotetext{
15 Inclusive, durante a sétima reunião da subcomissão, o ministro Alberto Hoffmann admitiu que o consenso com os demais tribunais não era total, ao afirmar que havia o desejo de vincular o Tribunal de Contas a um capítulo dentro do Título do Poder Judiciário, e também a pretensão de adquirir um capítulo próprio na Constituição. No entanto, os ministros Fernando Gonçalves e Alberto Hoffmann acabaram manifestando o desejo de parte dos tribunais de vincular o TCU, na Carta Constitucional, ao Congresso.
} 


\section{Quadro 1 \\ Propostas dos ministros do TCU à Subcomissão do Orçamento e Fiscalização Financeira}

\begin{tabular}{|c|c|}
\hline Classificação & Propostas \\
\hline $\begin{array}{l}\text { Atribuição } \\
\text { (geral) }\end{array}$ & Controle externo do Congresso exercido com o auxílio do Tribunal de Contas. \\
\hline \multirow{2}{*}{ Jurisdição } & Tribunal de Contas com jurisdição em todo o país. \\
\hline & $\begin{array}{c}\text { Controle do Congresso sobre a administração pública direta e indireta (com o auxílio } \\
\text { do Tribunal de Contas). }\end{array}$ \\
\hline \multirow{4}{*}{$\begin{array}{l}\text { Fiscalização / } \\
\text { Jurisdição }\end{array}$} & $\begin{array}{c}\text { Parecer do Tribunal de Contas sobre as contas do governo da União, a serem } \\
\text { julgadas pelo Congresso. }\end{array}$ \\
\hline & Apreciação das contas do governo da União pelo Tribunal. \\
\hline & $\begin{array}{l}\text { Inspeções e auditorias nas unidades administrativas dos Poderes Legislativo, } \\
\text { Executivo e Judiciário. }\end{array}$ \\
\hline & $\begin{array}{c}\text { Fiscalização das entidades supranacionais de cujo capital social o poder público } \\
\text { participe. }\end{array}$ \\
\hline \multirow{2}{*}{$\begin{array}{l}\text { Julgamento / } \\
\text { Jurisdição }\end{array}$} & $\begin{array}{l}\text { Julgamento, pelo Tribunal de Contas, dos atos e das contas da administração, direta } \\
\text { e indireta, responsável por dinheiros, bens e valores públicos. }\end{array}$ \\
\hline & $\begin{array}{l}\text { Julgamento, para fins de registro, dos atos de nomeação para cargos e de } \\
\text { concessões iniciais de aposentadoria, reformas e pensões. }\end{array}$ \\
\hline Sanção & Aplicação de sanções previstas em lei. \\
\hline $\begin{array}{l}\text { Sanção / } \\
\text { Autonomia }\end{array}$ & $\begin{array}{c}\text { Em caso de ilegalidade, definição de prazo para correções e sustação da execução do } \\
\text { ato, caso o Tribunal não seja atendido. }\end{array}$ \\
\hline \multirow{5}{*}{ Autonomia } & $\begin{array}{c}\text { Prestação de informações sobre fiscalização, auditorias e inspeções pelo Tribunal ao } \\
\text { Congresso Nacional. }\end{array}$ \\
\hline & $\begin{array}{c}\text { Informações prestadas pelo Tribunal ao Congresso referentes a decisões sobre } \\
\text { legalidade de despesas e irregularidade de contas. }\end{array}$ \\
\hline & $\begin{array}{c}\text { Definição de normas para o exercício do controle externo, a serem fixadas pelo } \\
\text { próprio Tribunal. }\end{array}$ \\
\hline & $\begin{array}{c}\text { Organização interna por iniciativa própria (escolha de presidente, composição de } \\
\text { cargos, regimento interno, liberdade administrativa). }\end{array}$ \\
\hline & Subdivisões institucionais internas, a serem definidas em lei. \\
\hline
\end{tabular}

Fonte: Elaborado pelo autor com base na $7^{a}$ Reunião da Subcomissão do Orçamento e Fiscalização Financeira da Assembleia Nacional Constituinte (Brasil, 1987a, p. 127-128).

Deve-se ressaltar que os ministros se omitiram quanto aos dispositivos relacionados à independência institucional do órgão. Entretanto, como veremos adiante, os ministros ameaçaram a reputação dos constituintes com uma grande operação de fiscalização quando, no final do Processo Constituinte, sua garantia de vitaliciedade não foi aprovada. Ainda durante o funcionamento da subcomissão, os ministros se abstiveram de 
propor o método de sua própria seleção, com o argumento de que não estavam interessados em opinar sobre matérias de caráter político, as quais seriam de competência exclusiva dos constituintes. Segundo o ministro Alberto Hoffmann:

A definição da forma de organização do Tribunal, bem como do processo de nomeação e das prerrogativas de seus ministros, constitui matéria de natureza política, cabendo à soberania da Assembleia Nacional Constituinte sobre elas decidir (Brasil, 1987a, p. 128).

O constituinte Messias Góis (PFL) foi um dos principais apoios do Tribunal de Contas na subcomissão. Além de convidar os ministros para expor suas demandas aos membros da subcomissão, Góis encaminhou propostas em consonância com os objetivos dos ministros e declarou publicamente seu apoio ao fortalecimento dos Tribunais de Contas como a melhor solução para o controle financeiro ${ }^{16}$. Segundo Góis:

A condição humana diz da fraqueza (...). Como não temos uma fita métrica para medir caracteres, nem encontramos nas prateleiras dos supermercados honestidades à venda, é necessário que haja um poder, um organismo de certo modo colocado fora da paixão política, mesmo que seus membros, como ocorre no Brasil - e é bom que ocorra -, tenham vindo, a maioria, da classe política, porque sabem avaliar o momento (...) (Brasil, 1987a, 6a Reunião, p. 130).

Ao contrário dos dirigentes do TCU, Messias Góis não se eximiu de declarar sua preferência sobre o modo de seleção dos ministros. Contrário à seleção por concurso, propunha que o Executivo deveria escolher os ministros, estes sujeitos à aprovação do Congresso. Alguns constituintes dos partidos PFL e PDS, inclusive o presidente e o relator da subcomissão, também declararam seu apoio aos ministros do Tribunal ${ }^{17}$.

O anteprojeto do relator, José Luiz Maia (PDS), estava de acordo com quase todas as demandas levantadas pelos ministros do Tribunal de Contas e por Messias Góis (PFL). O Quadro 2 expõe as alterações. O relator fortaleceu as atribuições do TCU ao impor sanções aos agentes condenados, além de permitir a apreciação de contas a partir de critérios de economicidade, eficiência e eficácia, tornando-o uma instituição de controle não mais restrita a mera apreciadora da legalidade de contas.

O anteprojeto também conferia independência ao órgão por meio de garantias de vitaliciedade e inamovibilidade do cargo aos ministros, embora coubesse ao presidente da República a nomeação para esse cargo. No entanto, buscou limitar algumas atribuições do Tribunal de Contas em jurisdições específicas que poderiam comprometer a autoridade das

\footnotetext{
16 Os Tribunais de Contas, segundo seu argumento, seriam instituições neutras e apolíticas, e teriam a capacidade técnica necessária para desenvolver os trabalhos de controle financeiro.

17 Os constituintes que declararam apoio aos ministros do TCU publicamente foram: o presidente da subcomissão João Alves (PFL), o relator José Luiz Maia (PDS), Messias Góis e Furtado Leite (PFL).
} 
instituições representativas. Ou seja, nem mesmo os constituintes que apoiavam os ministros estavam dispostos a combinar regras de independência e autoridade ilimitada.

\section{Quadro 2 \\ Mudanças no anteprojeto da Subcomissão do Orçamento e Fiscalização Financeira pelo relator}

\begin{tabular}{|l|c|}
\hline Classificação & \multicolumn{1}{c|}{ Propostas } \\
\hline $\begin{array}{l}\text { Fiscalização / } \\
\text { Julgamento }\end{array}$ & $\begin{array}{r}\text { Fiscalização e julgamento com base em critérios de eficácia, eficiência, } \\
\text { economicidade e legitimidade. }\end{array}$ \\
\hline $\begin{array}{l}\text { Julgamento / } \\
\text { Jurisdição }\end{array}$ & $\begin{array}{r}\text { Exclusão de prerrogativa de registrar e julgar as nomeações para cargos } \\
\text { públicos e concessões de aposentadorias, reformas e pensões. }\end{array}$ \\
\hline $\begin{array}{l}\text { Sanção / } \\
\text { Jurisdição }\end{array}$ & $\begin{array}{r}\text { Em caso de contrato sustado, a parte prejudicada poderia solicitar recurso ao } \\
\text { Congresso Nacional, sem efeito suspensivo. }\end{array}$ \\
\hline \multirow{3}{*}{ Sanção } & Imposição de multa proporcional ao dano causado ao patrimônio. \\
\cline { 2 - 3 } & Inabilitação para o exercício da função pública de cinco a quinze anos. \\
\cline { 2 - 3 } & $\begin{array}{r}\text { Imponãa de débitos com eficácia de sentença e título executivo. } \\
\text { caso de omissão em comunicar irregularidades ao TCU. }\end{array}$ \\
\hline \multirow{2}{*}{ Independência } & Nomeação dos ministros pelo presidente da República. \\
\cline { 2 - 3 } & Garantias de vitaliciedade e inamovibilidade do cargo. \\
\hline
\end{tabular}

Fonte: Elaborado pelo autor com base em Brasil (1987a).

Nenhum constituinte da subcomissão discordou do fortalecimento das atribuições do Tribunal de Contas ${ }^{18}$. As divergências ocorreram em virtude dos dispositivos relacionados à independência do órgão, os quais poderiam ameaçar a soberania do Congresso Nacional. Adhemar de Barros Filho (PMDB) defendeu que os ministros deveriam ser escolhidos por voto majoritário do Legislativo, a fim de obter controle financeiro mais eficiente sobre o Executivo. Jessé Freire (PFL), por sua vez, com a justificativa de evitar interferência do Executivo sobre as fiscalizações e preservar a função de auxiliar do Congresso, defendeu a seleção dos ministros por concurso público, enquanto Messias Góis (PFL) alertava que essa medida poderia alocar pessoas não capacitadas para a função. Para garantir a presença de ministros capacitados, Góis propunha a escolha pelo Executivo, mas com a aprovação do Congresso para limitar a interferência do presidente ${ }^{19}$.

18 Apenas dois constituintes propuseram a extinção do Tribunal de Contas. Jutahy Magalhães (PSDB) apresentou a proposta de criar uma Auditoria Geral na Comissão do Sistema Tributário, Orçamento e Finanças (Brasil, 1987a, p. 200) e o constituinte João Natal (PMDB) propôs posteriormente em Plenário a substituição do Tribunal de Contas por uma Auditoria Geral do Congresso.

19 Brasil (1987a). 
O anteprojeto da subcomissão foi votado em bloco e aprovado. Ambos os conjuntos de emendas aprovadas e rejeitadas pelo relator foram aprovados respectivamente por $57,1 \%$ e $52,6 \%$ dos constituintes contra $42,9 \%$ e $47,4 \%$ de ausências. Os votos pela aprovação do anteprojeto partiram majoritariamente de constituintes do próprio PDS. De qualquer forma, o projeto poderia ser alterado na próxima comissão, onde lideranças de esquerda do PMDB teriam maior poder decisório.

\section{Nova composição de forças na Comissão Temática}

Segundo as regras regimentais, o trâmite dos trabalhos nas comissões temáticas seria semelhante ao das subcomissões. A partir do anteprojeto produzido na subcomissão, - relator da nova comissão seria responsável por organizar os novos pedidos de emendamento, aprovando-os ou rejeitando-os livremente. Em seguida submeteria a nova versão à votação por maioria absoluta dos integrantes da comissão em bloco. A Comissão do Sistema Tributário, Orçamento e Finanças foi presidida por Francisco Dornelles (PFL) e, ao contrário da subcomissão anterior, contou com um relator considerado de esquerda, o constituinte José Serra (PMDB).

Durante as reuniões, os debates a respeito dos Tribunais de Contas foram extremamente escassos em meio a outros assuntos de ordem financeira. As justificativas anexadas às propostas de emendamento são as principais fontes empíricas do posicionamento dos constituintes na Comissão, além dos pareceres do relator, que justificavam a rejeição ou a aprovação das emendas.

Foram inúmeras as emendas propostas por constituintes. Com exceção de uma ${ }^{20}$, todas reconheciam que o exercício do controle externo deveria ser realizado pelo Tribunal de Contas. O conteúdo de muitas emendas era semelhante e, como o regimento interno possibilitava a aceitação parcial de emendas, é difícil encontrar a verdadeira origem de cada proposta aceita pelo relator ${ }^{21}$. As poucas emendas aprovadas de autoria claramente identificável partiram exclusivamente de constituintes do PDT e do PMDB. De qualquer forma, fica claro o papel crucial do relator que, no primeiro momento, poderia selecionar o que lhe fosse mais oportuno.

As mudanças introduzidas pelo relator em relação ao projeto anterior buscaram diminuir o rol de jurisdicionados vinculados a algumas atribuições, bem como limitar a autonomia do TCU e as garantias de independência dos ministros, como mostra o Quadro 3. Os recursos repassados pela União a outras esferas de governo só poderiam ser fiscalizados se estivessem dispostos em forma de convênio, e o Tribunal não poderia inabilitar agentes para exercício de cargo público em caso de irregularidades. O Congresso

\footnotetext{
20 Jutahy Magalhães (PSDB) apresentou a proposta de substituir o TCU por um modelo institucional de Auditoria Geral (Brasil, 1987a, p. 200).

${ }^{21}$ Ademais, muitas das emendas procuravam substituir expressões visando apenas aumentar a clareza do conteúdo, sem alterar o sentido da medida.
} 
passou a ter o recurso de solicitar serviços compulsórios de parecer técnico em casos de suspeitas de irregularidades e, mais importante, apenas um terço dos ministros, indicados pelo presidente da República com aprovação do Congresso, seria vitalício, enquanto dois terços, escolhidos exclusivamente pelo Congresso, ocupariam cargos por seis anos não renováveis. Em outras palavras, o Congresso teria o poder de demitir a maior parte dos ministros caso desejasse, diminuindo a independência do órgão.

\section{Quadro 3 \\ Mudanças no anteprojeto da Comissão do Sistema Tributário, Orçamento e Finanças pelo relator}

\begin{tabular}{|c|c|}
\hline Classificação & Propostas \\
\hline \multirow{2}{*}{$\begin{array}{l}\text { Fiscalização / } \\
\text { Jurisdição }\end{array}$} & Qualquer pessoa física ou jurídica estaria sujeita à prestação de contas. \\
\hline & $\begin{array}{l}\text { Fiscalização de recursos repassados pela União a outras esferas de governo } \\
\text { somente em forma de convênio. }\end{array}$ \\
\hline $\begin{array}{l}\text { Sanção / } \\
\text { Jurisdição }\end{array}$ & Exclusão de inabilitação de agentes para exercício de cargo público. \\
\hline Autonomia & $\begin{array}{l}\text { Congresso pode solicitar compulsoriamente serviços de parecer técnico em } \\
\text { casos de suspeitas de irregularidades. }\end{array}$ \\
\hline \multirow{2}{*}{ Independência } & $\begin{array}{l}\text { Prestação obrigatória de informação das atividades do Tribunal ao Congresso } \\
\text { por meio de relatórios anuais. }\end{array}$ \\
\hline & $\begin{array}{l}\text { Vitaliciedade para um terço dos ministros, indicados pelo presidente da } \\
\text { República com aprovação do Congresso. Dois terços dos ministros escolhidos } \\
\text { pelo Congresso com mandato de seis anos não renováveis. }\end{array}$ \\
\hline
\end{tabular}

Fonte: Elaborado pelo autor com base em Brasil (1987a).

Mesmo com as novas limitações ao poder institucional do TCU, constituintes se mantiveram preocupados com a possibilidade de o Tribunal ameaçar a soberania de instituições representativas. O constituinte Cid de Sabóia de Carvalho (PMDB), por exemplo, questionou a amplitude do rol de jurisdicionados no anteprojeto do relator, devido ao risco de o TCU intervir sobre a autonomia dos governos subnacionais. Para José Serra (PMDB), esse problema estaria sanado, porque o Tribunal só fiscalizaria recursos voluntariamente repassados pela União mediante convênio. A passagem a seguir reflete o receio de Serra de atribuir muito poder ao Tribunal de Contas:

(...) não criamos um monstro. Poderemos ter criado até um insetozinho, mas não um monstro. Pelo que V. Ex. ${ }^{a}$ assinala, haveria esse monstro, caso realmente essa fiscalização se estendesse às transferências, aos recursos partilhados etc. (Brasil, 1987a). 
Apenas um constituinte da comissão, Jutahy Magalhães (PSDB), apresentou proposta para substituição do TCU por uma Auditoria Geral da República, a qual não foi atendida. Segundo sua justificativa, a fiscalização financeira era ineficiente e o Congresso deveria ter um órgão ainda mais subordinado às suas necessidades técnicas. O presidente do Senado deveria escolher o Auditor Geral com a aprovação das duas casas legislativas.

As propostas dos demais constituintes se restringiam a ajustes ao anteprojeto, sem nenhuma pretensão de extinguir o Tribunal de Contas. Seguindo as lideranças do PDS e PFL da subcomissão anterior, José Serra (PMDB) defendeu a continuidade do órgão de controle em seu anteprojeto:

Em primeiro lugar, porque creio que não se necessita de um dispositivo na Constituição para que o Congresso possa recorrer eventualmente a serviços de auditoria (...). Por outro lado, se há deficiência no trabalho do Tribunal de Contas, devemos procurar corrigi-lo, mais do que procurar criar outro órgão para suprir esse órgão que, supostamente, não está funcionando adequadamente (Brasil, 1987a).

Tanto as emendas com parecer favorável quanto as emendas com parecer contrário por parte do relator foram votadas em bloco. A Tabela 1 apresenta os votos por partido e a proporção de votos em relação às cadeiras do respectivo partido. No entanto, a evidência não é adequada para inferir o posicionamento de todos os constituintes quanto ao desenho institucional do TCU, porque as emendas votadas em bloco envolviam predominantemente dispositivos constitucionais de ordem financeira, não se limitando ao desenho institucional do TCU. Consequentemente, rejeitar o anteprojeto do relator significaria não apenas se opor ao modelo de controle de contas, mas também desaprovar todos os dispositivos de ordem orçamentária. Os três maiores partidos da Comissão PMDB, PDS e PFL - somavam $82,0 \%$ dos votantes e quase todos os seus membros participaram da votação, aprovando o anteprojeto. 
Tabela 1

Votação do Anteprojeto do Relator de acordo com partidos na Comissão do Sistema Tributário, Orçamento e Finanças

\begin{tabular}{|l|c|c|c|c|c|c|c|c|c|c|c|}
\hline Posicionamento & & PMDB & PFL & PDS & PDT & PT & PTB & PCB & PCdoB & PDC & Total \\
\hline \multirow{3}{*}{ Sim } & $\mathrm{N}$ & 24 & 11 & 10 & 0 & 0 & 1 & 1 & 0 & 2 & 49 \\
\cline { 2 - 13 } & $\%$ & 88,9 & 100,0 & 83,3 & 0,0 & 0,0 & 100,0 & 50,0 & 0,0 & 66,7 & 80,3 \\
\hline \multirow{2}{*}{ Não } & $\mathrm{N}$ & 1 & 0 & 0 & 0 & 2 & 0 & 0 & 0 & 0 & 3 \\
\cline { 2 - 13 } & $\%$ & 3,7 & 0,0 & 0,0 & 0,0 & 100,0 & 0,0 & 0,0 & 0,0 & 0,0 & 3,7 \\
\hline \multirow{3}{*}{ Abstenções } & $\mathrm{N}$ & 1 & 0 & 0 & 0 & 0 & 0 & 0 & 0 & 0 & 1 \\
\cline { 2 - 13 } & $\%$ & 3,7 & 0,0 & 0,0 & 0,0 & 0,0 & 0,0 & 0,0 & 0,0 & 0,0 & 3,7 \\
\hline \multirow{3}{*}{ Ausências } & $\mathrm{N}$ & 1 & 0 & 2 & 1 & 0 & 0 & 1 & 2 & 1 & 8 \\
\cline { 2 - 12 } & $\%$ & 3,7 & 0,0 & 16,7 & 100,0 & 0,0 & 0,0 & 50,0 & 100,0 & 33,3 & 3,7 \\
\hline \multirow{3}{*}{ Total } & $\mathrm{N}$ & 27 & 11 & 12 & 1 & 2 & 1 & 2 & 2 & 3 & 61 \\
\cline { 2 - 12 } & $\%$ & 44,3 & 18,0 & 19,7 & 1,6 & 3,3 & 1,6 & 3,3 & 3,3 & 4,9 & 100,0 \\
\hline
\end{tabular}

Fonte: Elaborada pelo autor com base na $9^{a}$ Reunião da Comissão do Sistema Tributário, Orçamento e Finanças (Brasil, 1987a).

O novo anteprojeto aprovado alterou o projeto da subcomissão anterior no sentido de subordinar ainda mais o Tribunal de Contas ao Congresso Nacional, limitando a independência dos ministros e o rol de jurisdicionados vinculados às atribuições fiscalizatórias e de sanção. Isso não significa que as lideranças da Comissão enfraqueceram o TCU de uma vez por todas. Afinal, os demais dispositivos aprovados na subcomissão anterior continuaram no novo anteprojeto, embora fossem estabelecidos novos limites à capacidade de intervenção do Tribunal sobre a atuação dos poderes representativos.

\section{Comissão de sistematização}

No dia 5 de janeiro de 1988, foi aprovado o novo regimento interno da Constituinte, o que criava oportunidades para que minorias propusessem alterações ao texto constitucional. Em um primeiro momento, os constituintes poderiam propor emendas de títulos, capítulos e dispositivos, coletiva ou individualmente - esse último limitado a quatro emendas -, sujeitas a aprovação ou rejeição pelo relator, que estava proibido de alterar o sentido original das propostas ${ }^{22}$. Em seguida, seria possível propor destaques para a votação de emendas em separado, caso houvesse apoio de no mínimo 187 (33,5\%) constituintes. Todas as votações seriam por maioria absoluta, favorecendo a vontade majoritária do plenário.

O relator da Comissão de Sistematização, Bernardo Cabral (PMDB), aumentou as atribuições e a jurisdição do TCU, mas diminuiu sua autonomia e não concedeu garantias

\footnotetext{
22 Para garantir a proibição de alterar o sentido das emendas originais, seus primeiros signatários deveriam
} assiná-las antes de submetê-las à votação (Brasil, 1988b, Parágrafo 2, Art. 3). 
de independência a todos os ministros. O Tribunal passou a fiscalizar aposentadorias e pensões, licitações e quaisquer repasses da União aos níveis subnacionais (Quadro 4). A autonomia dos controladores para definir prioridades foi restringida, dado que o Tribunal deveria analisar compulsoriamente denúncias de cidadãos, além de ser obrigado a prestar informações de suas atividades ao Congresso. Um terço dos ministros não contaria com vitaliciedade e teria tempo de mandato limitado a seis anos, deixando a instituição ainda suscetível a pressões políticas.

Embora o relator aumentasse o número de ministros protegidos pela vitaliciedade, tal mudança não refletia o interesse majoritário dos constituintes, como será apresentado adiante. Além disso, ao determinar que todas as denúncias deveriam ser averiguadas compulsoriamente, Bernardo Cabral (PMDB) comprometia a agenda do Tribunal, diminuindo sua esfera de autonomia.

Quadro 4

Mudanças no anteprojeto da Comissão de Sistematização pelo relator

\begin{tabular}{|l|c|}
\hline \multirow{2}{*}{ Classificação } & Propostas \\
\hline \multirow{2}{*}{$\begin{array}{l}\text { Fiscalização / } \\
\text { Jurisdição }\end{array}$} & Apreciação de aposentadorias e pensões. \\
\cline { 2 - 2 } & Acompanhamento de licitações. \\
\hline $\begin{array}{l}\text { Sanção / } \\
\text { Jurisdição }\end{array}$ & Análise compulsória de denúncias probre quaisquer repasses da União aos níveis subnacionais. \\
\hline Autonomia & Impugnação de licitações. \\
\hline \multirow{2}{*}{\begin{tabular}{l} 
Independência \\
\cline { 2 - 2 }
\end{tabular}} & Dos onze ministros, vitaliciedade para dois terços e mandato de seis anos não \\
\cline { 2 - 2 } & renováveis para um terço. \\
\hline
\end{tabular}

Fonte: Elaborado pelo autor com base em Brasil (1987a).

Até essa etapa do Processo Constituinte, a preferência dos constituintes esteve em consonância com parte da literatura de judicial review, segundo a qual atores políticos conferem independência e delegam atribuições aos controladores para limitar seus adversários no futuro (Chavez, 2004; Finkel, 2008; Ginsburg, 2003; Magaloni, 2008; Ramseyer, 1994; Stephenson, 2003), principalmente quando os atores políticos têm certeza quanto à composição futura do órgão (Knight, 2001). Em um momento de incerteza eleitoral em meio à transição democrática e de desgaste da imagem do governo autoritário, partidos provenientes da Arena preferiam fortalecer o poder de controle do TCU, enquanto os opositores do regime militar, representados pela esquerda do PMDB, preferiam impor limites ao órgão de controle. No entanto, veremos a seguir que, mesmo 
o PMDB contando com maioria no Congresso, os constituintes não conseguiram evitar que - Tribunal de Contas conquistasse a garantia institucional que the conferia maior independência: a vitaliciedade.

\section{O Plenário e a vontade da maioria}

Contrariando o posicionamento dos relatores da segunda Comissão e da Comissão de Sistematização em favor de limitar o poder de controle do TCU sobre as instituições representativas, as emendas aprovadas em plenário mudaram a direção que o desenho institucional do órgão vinha tomando, aumentando sua autonomia e independência. Em meio ao contexto de incerteza futura, próprio da transição democrática, o Tribunal de Contas pressionou os constituintes ao anunciar publicamente a Operação Transparência, a qual poderia impor custos políticos a integrantes dos maiores partidos que haviam participado da gestão de recursos públicos durante o mandato anterior. Poucas foram as emendas referentes ao Tribunal de Contas encaminhadas à votação em Plenário. Apenas o PMDB, PFL e PDS conseguiram os 187 apoios necessários para propor emendas. Das emendas propostas, muitas foram retiradas por seus próprios autores em meio às negociações. O Quadro 5 sintetiza as emendas aprovadas, classificando-as segundo as dimensões do desenho institucional do Tribunal. Em direção oposta às decisões tomadas pelos relatores do PMDB nas comissões anteriores, os novos dispositivos aprovados em Plenário asseguravam independência e autonomia institucional aos ministros do TCU. Todos os ministros passaram a contar com vitaliciedade e sua escolha dependeria menos do presidente da República. Caberia ao próprio órgão avaliar a viabilidade de denúncias de cidadãos, conferindo autonomia ao Tribunal quanto à definição de suas prioridades, e os ministros não seriam obrigados a executar inspeções e auditorias solicitadas pelo Ministério Público ao Tribunal de Contas. A única exceção envolvia a necessidade de abstenção do Congresso para que 0 TCU pudesse anular contratos com irregularidades sem consentimento dos atores políticos. 


\section{Quadro 5}

Mudanças no projeto de Constituição aprovadas pelo Plenário

\begin{tabular}{|c|c|}
\hline Classificação & Propostas \\
\hline $\begin{array}{l}\text { Sanção / } \\
\text { Jurisdição / } \\
\text { Autonomia }\end{array}$ & $\begin{array}{l}\text { Anulação de contratos irregulares apenas em casos de abstenção do Congresso } \\
\text { Nacional sobre o assunto. }\end{array}$ \\
\hline \multirow{2}{*}{ Independência } & $\begin{array}{l}\text { Ministros escolhidos pelo presidente da República provenientes de lista tríplice } \\
\text { elaborada pelo Tribunal de Contas a partir de seu corpo técnico. }\end{array}$ \\
\hline & Vitaliciedade para todos os ministros. \\
\hline \multirow{2}{*}{ Autonomia } & Cabe ao TCU avaliar a viabilidade das denúncias realizadas por cidadãos. \\
\hline & $\begin{array}{c}\text { Ministério Público impedido de solicitar inspeções e auditorias ao Tribunal de } \\
\text { Contas. }\end{array}$ \\
\hline
\end{tabular}

Fonte: Elaborado pelo autor com base em Brasil (1987a).

A única emenda que contou com voto nominal foi vitaliciedade do cargo de ministro e, por isso, a discussão em torno desse dispositivo configura uma evidência valiosa referente à força da Operação Transparência sobre o comportamento dos constituintes. Porém, não se deve perder de vista que os demais dispositivos de independência e autonomia apresentados no Quadro 5 também foram aprovados depois da ameaça de fiscalização. Antes de as emendas serem votadas, os ministros do Tribunal de Contas, que durante a primeira subcomissão se abstiveram de debater a questão por não se tratar de um assunto técnico, mas sim político, passaram a defender publicamente sua independência institucional, principalmente no que se refere à vitaliciedade. Segundo entrevista do ministro Jorge Vargas, concedida ao jornal O Estado de S. Paulo:

Seria desejável também, que os Constituintes, através de emenda supressiva, restituíssem a vitaliciedade ao TCU, mantida desde a sua criação em 1891, como forma de preservação de sua independência para julgar, como acontece com todos os outros tribunais superiores (O Estado de S. Paulo, 7 jul. 1988).

Após os resultados da Comissão de Sistematização, no dia 28 de julho de 1987, o presidente do TCU, Fernando Gonçalves, informou à imprensa que o Tribunal, a partir de 10 de agosto do mesmo ano - ainda durante os trabalhos constituintes -, iniciaria a Operação Transparência, que pretendia fiscalizar repartições e empresas estatais quanto a licitações, contratos, contratação de pessoal, além de diárias e passagens (Folha de $S$. Paulo, 29 jul. 1988). Ainda segundo o ministro, a Operação Transparência teria sido solicitada por José Sarney (PDS) (Folha de S. Paulo, 9 ago. 1988). A operação pode ser interpretada como ameaça aos maiores partidos, visto que, naquele contexto de incerteza 
política da transição democrática, poderia trazer custos políticos aos atores que participaram da administração de recursos públicos na última gestão.

Após o anúncio da Operação Transparência, membros dos maiores partidos passaram a apoiar a vitaliciedade dos ministros publicamente. Ao contrário das comissões anteriores, que ressaltaram a preocupação dos constituintes em limitar o tempo de mandato dos ministros para manter o Tribunal subordinado ao Congresso Nacional, integrantes dos maiores partidos, inclusive forças contrárias ao regime militar, passaram a defender a aprovação de garantias de independência aos ministros. O discurso do constituinte João Agripino (PMDB) ilustra essa preocupação:

É importante frisar, Sr. Presidente, Sr. Relator, que a função do Juiz é, através dos tempos, protegida pela vitaliciedade. Não se dá vitaliciedade ao funcionário, mas ao cargo. E importante fazer essa distinção, porque não será o indivíduo que será vitalício no cargo, mas o seu cargo. Para que ele possa desempenhar as suas funções judicantes é que deve ser protegido pela vitaliciedade (...). Tirar a vitaliciedade do Ministro do Tribunal de Contas da União é fazer com que ele perca a garantia de estar sob pressão, porque ele terá apenas um mandato de seis anos e terá que voltar à vida pública e, assim, estará sujeito a todo tipo de pressão ainda mais que assumimos a responsabilidade de indicar dois terços desses Ministros (Brasil, 1988a, p. 167-168).

Victor Facione (PDS), vinculado à situação do regime militar, utilizou um argumento semelhante:

(...) quer me parecer, a vitaliciedade, uma tradição de mais de cem anos na vida do nosso País, é uma condição que tem sido assegurada a todos os Membros de todas as Cortes, que têm a difícil missão de julgar, quer no Judiciário, quer nos Tribunais de Contas (...). A tranquilidade que os Ministros devem ter para o julgamento e apreciação das contas está aí no exame do dia a dia de tudo quanto é tipo de pressão que se nota, que se apercebe na vida política administrativa do País (Brasil, 1988a, p. 182).

Quando colocada em plenário, a emenda favorável à vitaliciedade foi rejeitada pela maioria dos votos e dividiu os constituintes. Os líderes dos maiores partidos - PMDB, PFL, PDS e PDT - anunciaram publicamente sua orientação favorável à vitaliciedade para as suas respectivas bancadas, mas não obtiveram sucesso. A Tabela 2 apresenta o resultado da votação e a proporção de votos em relação ao número de cadeiras de cada partido com exceção da última coluna, que indica a proporção de cada bancada em relação a todos os constituintes. Apenas 36,7\% votaram favoravelmente à vitaliciedade. Nos três maiores partidos, houve elevada taxa de ausências, indicando o pequeno interesse dos constituintes sobre a matéria. Entre os maiores partidos, o PDS apresentou maior taxa de apoio à 
vitaliciedade (55\%). Por outro lado, mesmo sob a nova orientação dos líderes pela aprovação da vitaliciedade, cerca de um terço dos constituintes presentes do PMDB e do PFL se posicionou contra a medida.

Tabela 2

Votação sobre vitaliciedade do $1^{\circ}$ turno em Plenário

\begin{tabular}{|l|c|c|c|c|c|c|c|c|c|c|}
\hline & \multicolumn{2}{|c|}{ Aprovações } & \multicolumn{2}{c|}{ Rejeições } & \multicolumn{2}{c|}{ Abstenções } & \multicolumn{2}{|c|}{ Ausências } & \multicolumn{2}{c|}{ Total } \\
\hline Partidos & $\mathbf{N}$ & $\mathbf{\%}$ & $\mathbf{N}$ & $\mathbf{\%}$ & $\mathbf{N}$ & $\mathbf{\%}$ & $\mathbf{N}$ & $\%$ & $\mathbf{N}$ & $\%$ \\
\hline PMDB & 119 & 40,1 & 69 & 23,2 & 3 & 1,0 & 106 & 35,7 & 297 & 53,2 \\
\hline PFL & 43 & 32,6 & 14 & 10,6 & 0 & 0,0 & 75 & 56,8 & 132 & 23,7 \\
\hline PDS & 22 & 55,0 & 2 & 5,0 & 0 & 0,0 & 16 & 40,0 & 40 & 7,2 \\
\hline PDT & 10 & 40,0 & 6 & 24,0 & 1 & 4,0 & 8 & 32,0 & 25 & 4,5 \\
\hline PTB & 6 & 33,3 & 8 & 44,4 & 0 & 0,0 & 4 & 22,2 & 18 & 3,2 \\
\hline PT & 0 & 0,0 & 16 & 100,0 & 0 & 0,0 & 0 & 0,0 & 16 & 2,9 \\
\hline PSDB & 0 & 0,0 & 6 & 75,0 & 0 & 0,0 & 2 & 25,0 & 8 & 1,4 \\
\hline PDC & 1 & 20,0 & 1 & 20,0 & 0 & 0,0 & 3 & 60,0 & 5 & 0,9 \\
\hline PL & 3 & 60,0 & 1 & 20,0 & 0 & 0,0 & 1 & 20,0 & 5 & 0,9 \\
\hline PCB & 0 & 0,0 & 3 & 100,0 & 0 & 0,0 & 0 & 0,0 & 3 & 0,5 \\
\hline PCdoB & 0 & 0,0 & 3 & 100,0 & 0 & 0,0 & 0 & 0,0 & 3 & 0,5 \\
\hline PSB & 0 & 0,0 & 3 & 100,0 & 0 & 0,0 & 0 & 0,0 & 3 & 0,5 \\
\hline PMB & 0 & 0,0 & 0 & 0,0 & 0 & 0,0 & 2 & 100,0 & 2 & 0,4 \\
\hline PSC & 1 & 100,0 & 0 & 0,0 & 0 & 0,0 & 0 & 0,0 & 1 & 0,2 \\
\hline Total & 205 & 36,7 & 132 & 23,7 & 4 & 0,7 & 217 & 38,9 & 558 & 100,0 \\
\hline
\end{tabular}

Fonte: Elaborada pelo autor com base na 323a Sessão (Brasil, 1988a, p. 168-170).

Segundo o Regimento Interno, qualquer dispositivo constitucional não poderia ser votado mais de uma vez. Entretanto, contrariando o regimento, dois dias após a votação, a matéria foi direcionada novamente para apreciação em plenário, o que reforça a ideia de que a Operação Transparência trazia elevados custos políticos às lideranças. Apenas integrantes de pequenos partidos que não participaram diretamente da gestão de recursos públicos - e que, portanto, estavam fora do alcance da Operação Transparência contestaram o descumprimento do regimento ${ }^{23}$.

A Tabela 3 mostra o resultado da nova votação e a proporção de votos em relação ao número de cadeiras de cada partido - com exceção da última coluna que indica a proporção de cada bancada em relação a todos os constituintes. No total, $52 \%$ dos constituintes votaram favoravelmente à vitaliciedade. O resultado foi revertido

23 Brasil (1988b, 327a sessão). 
principalmente com o apoio de membros do PMDB e PFL, que anteriormente haviam rejeitado a matéria ou que estavam ausentes durante a votação.

Tabela 3

Votação sobre vitaliciedade do $2^{\circ}$ turno em Plenário

\begin{tabular}{|l|c|c|c|c|c|c|c|c|c|c|}
\hline & \multicolumn{2}{|c|}{ Aprovação } & \multicolumn{2}{c|}{ Rejeição } & \multicolumn{2}{c|}{ Abstenções } & \multicolumn{2}{|c|}{ Ausências } & \multicolumn{2}{c|}{ Total } \\
\hline Partidos & $\mathbf{N}$ & $\mathbf{\%}$ & $\mathbf{N}$ & $\mathbf{\%}$ & $\mathbf{N}$ & $\mathbf{\%}$ & $\mathbf{N}$ & $\mathbf{\%}$ & $\mathbf{N}$ & $\%$ \\
\hline PMDB & 157 & 52,9 & 54 & 18,2 & 1 & 0,3 & 85 & 28,6 & 297 & 53,2 \\
\hline PFL & 75 & 56,8 & 6 & 4,5 & 0 & 0,0 & 51 & 38,6 & 132 & 23,7 \\
\hline PDS & 23 & 57,5 & 3 & 7,5 & 0 & 0,0 & 14 & 35,0 & 40 & 7,2 \\
\hline PDT & 14 & 56,0 & 3 & 12,0 & 0 & 0,0 & 8 & 32,0 & 25 & 4,5 \\
\hline PTB & 12 & 66,7 & 0 & 0,0 & 0 & 0,0 & 6 & 33,3 & 18 & 3,2 \\
\hline PT & 0 & 0,0 & 15 & 93,8 & 0 & 0,0 & 1 & 6,3 & 16 & 2,9 \\
\hline PSDB & 2 & 25,0 & 4 & 50,0 & 0 & 0,0 & 2 & 25,0 & 8 & 1,4 \\
\hline PDC & 3 & 60,0 & 0 & 0,0 & 0 & 0,0 & 2 & 40,0 & 5 & 0,9 \\
\hline PL & 4 & 80,0 & 0 & 0,0 & 0 & 0,0 & 1 & 20,0 & 5 & 0,9 \\
\hline PCB & 0 & 0,0 & 3 & 100,0 & 0 & 0,0 & 0 & 0,0 & 3 & 0,5 \\
\hline PCdoB & 0 & 0,0 & 3 & 100,0 & 0 & 0,0 & 0 & 0,0 & 3 & 0,5 \\
\hline PSB & 0 & 0,0 & 3 & 100,0 & 0 & 0,0 & 0 & 0,0 & 3 & 0,5 \\
\hline PMB & 0 & 0,0 & 0 & 0,0 & 0 & 0,0 & 2 & 100,0 & 2 & 0,4 \\
\hline PSC & 0 & 0,0 & 1 & 100,0 & 0 & 0,0 & 0 & 0,0 & 1 & 0,2 \\
\hline Total & 290 & 52,0 & 95 & 17,0 & 1 & 0,2 & 172 & 30,8 & 558 & 100,0 \\
\hline
\end{tabular}

Fonte: Elaborada pelo autor com base na $327^{a}$ sessão (Brasil, 1988a, p. 430-432).

A Operação Transparência é a única evidência observável entre, de um lado, a adoção de limites ao poder de controle conferido ao TCU pelas relatorias da segunda Comissão e da Comissão de Sistematização e, de outro, as emendas para votação em plenário que buscaram assegurar maior autonomia e independência ao órgão. As ameaças do Tribunal de Contas motivaram as lideranças dos maiores partidos a mobilizar suas bancadas em favor dos interesses dos ministros, independentemente da preferência inicial dos constituintes e de sua força institucional, medida pelo número de cadeiras e pela ocupação de postos de relatoria. Nas fases iniciais do Processo Constituinte, os líderes da maior bancada, o PMDB, buscaram restringir a independência e a autonomia do TCU, subordinando-o ainda mais à soberania do Congresso Nacional, mas mudaram de posicionamento após o órgão de controle ameaçá-los com a Operação Transparência.

Inclusive, a Operação Transparência desapareceu dos principais jornais do país após a aprovação da vitaliciedade. Satisfeitos com um modelo que previa amplas 
prerrogativas, autonomia e independência institucional, a pretensão de fiscalizar amplamente os atores que participaram da gestão anterior chegou ao fim. Embora as bancadas permanecessem divididas, a ameaça conferida pela Operação Transparência foi suficiente para mobilizar as lideranças dos maiores partidos e, assim, mudar o curso que o desenho institucional do Tribunal estava tomando, introduzindo regras para proteger a independência do órgão.

\section{Discussão}

O presente artigo pretendeu explicar o que motiva atores políticos a conferir independência e maior poder de controle a instituições de combate à corrupção, sob o risco de serem controlados no futuro. O desenho institucional do Tribunal de Contas da União aprovado na Constituinte de 1988 criou oportunidades de controle sobre as instituições representativas, não apenas devido à ampla jurisdição e às vastas atribuições de controle conferidas ao órgão, como também em virtude das garantias de independência e da autonomia institucional. Independentemente das preferências iniciais dos atores políticos e da força dos partidos, medida pelo número de cadeiras e pela ocupação em postos de relatoria, somente após o TCU ameaçar a sobrevivência política dos constituintes com uma ampla operação de fiscalização, as lideranças dos maiores partidos mobilizaram suas bancadas para conceder garantias de independência ao órgão de controle. Com isso, os constituintes evitaram os custos de enfrentar fiscalizações em meio ao contexto de incerteza futura, próprio da transição democrática, assumindo o risco de criar uma instituição de controle capaz de comprometer futuramente a soberania das instituições representativas sobre a gestão de recursos.

Assim como a literatura sobre a adoção da judicial review previu, as preferências das lideranças políticas nas primeiras fases do processo dependeram de expectativas quanto à competição eleitoral e à composição do órgão de controle. Partidos provenientes da situação do regime militar - a qual foi responsável pela escolha de praticamente todos os ministros que compunham o TCU durante a Constituinte - pretenderam conferir maior poder institucional aos controladores, enquanto lideranças provenientes da oposição ao governo autoritário mostraram preferência por preservar a soberania do Congresso Nacional. Porém, mesmo os partidos vinculados ao regime militar não desconsideravam que limites deveriam ser impostos ao TCU.

De qualquer forma, as evidências sugerem que o protagonismo do Tribunal de Contas foi capaz de alterar as preferências dos líderes da oposição ao regime militar por meio de ameaças à sua sobrevivência política. Tal diagnóstico questiona se regras de independência conferidas a instituições de combate à corrupção são o produto de disputas democráticas, visto que os interesses corporativos de atores não eleitos se sobrepuseram às preferências de representantes eleitos. 
A existência prévia de instituições de controle e seu ativismo são indispensáveis para a compreensão da evolução das instituições com garantias de independência (Hirschl, 2004). Decorridos os primeiros anos da nova democracia brasileira, instituições públicas de auditoria financeira foram fortalecidas, assim como instituições do sistema de justiça (Arantes e Moreira, 2017; Arantes, 2002, 2011; Loureiro, Teixeira e Morais, 2009; Olivieri, 2010). Mesmo assim, integrantes dos tribunais de contas continuam reivindicando seus interesses corporativos, e propostas de reforma institucional não cessam. Com a justificativa de uniformizar o controle de contas no país, membros dos tribunais de contas subnacionais passaram a defender a criação do Conselho Nacional dos Tribunais de Contas, que seria composto por um corpo diretivo incumbido de coordenar os órgãos de controle financeiro. O Conselho Nacional seria encarregado desde a apreciação da validade dos atos administrativos praticados pelos tribunais de contas até a adoção de providências para o cumprimento de normas ${ }^{24}$. Concorrentemente, surgiu até mesmo uma proposta para submeter os tribunais de contas à supervisão do Conselho Nacional de Justiça ${ }^{25}$. Estariam os controladores exclusivamente interessados em sanar problemas institucionais do controle de contas? Ou estariam à espreita de uma nova oportunidade para concentrar ainda mais poder institucional? Independentemente dos reais interesses dos atores, os achados sugerem que contextos de instabilidade política certamente não são os mais aconselháveis para tomar decisões definitivas sobre o assunto.

\section{Referências bibliográficas}

Arantes, R. B. Ministério Público e política no Brasil. São Paulo: Idesp/Sumaré, Educ., 2002.

. The Federal Police and the Ministério Público. In: POWER, T.; TAYLOR, M. (orgs.).

Corruption and democracy in Brazil. Notre Dame: University of Notre Dame Press, p. 184-217, 2011.

"Rendición de cuentas y pluralismo estatal en Brasil: Ministerio Público y Policía Federal". Desacatos, vol. 49, p. 28-47, set.-dez. 2015.

ARAntes, R. B.; MoreirA, T. "Expansão de controles democráticos? O desenvolvimento de instituições judiciais sob a ótica do pluralismo estatal". In: $41^{\circ}$ Encontro Anual da Anpocs, 2017.

ARRETCHE, M. "Federalismo e igualdade territorial: uma contradição em termos?". Dados - Revista de Ciências Sociais, vol. 53, no 3, p. 587-620, 2010.

\footnotetext{
24 Ver, por exemplo, artigo de Dimas Ramalho, presidente do Tribunal de Contas do Estado de São Paulo: <http://www.atricon.org.br/artigos/um-conselho-nacional-para-os-tribunais-de-contas/>. Acessp em: 27 jun. 2018.

25 Proposta de Emenda à Constituição de número 329/2013 foi iniciada tanto por integrantes de partidos da coalizão quanto da oposição, como Francisco Praciano (PT/AM), Paulo Rubem Santiago (PDT/PE), Rosane Ferreira (PV/PR), Izalci Ferreira (PSDB/DF), entre outros.
} 
BeACH, D.; Pedersen, R. B. Developing empirical tests of causal mechanisms. In: BeACH, D.; PEDERSEN, R. B. (orgs.). Process-tracing methods: foundations and guidelines. Ann Arbor: The University of Michigan Press, p. 95-119, $2013 a$.

Beach, D.; Pedersen, R. B. Turning observations into evidences. In: Beach, D.; Pedersen, R. B. (orgs.). Process-tracing methods: foundations and guidelines. Ann Arbor: The University of Michigan Press, p. 95-119, 2013b.

BRASIL. Ministros do Tribunal de Contas da União: dados biográficos. 7a ed. Brasília: TCU, Assessoria de Cerimonial e Relações Institucionais, 2008.

. Atas da Assembleia Nacional Constituinte, Diário da Assembleia Nacional Constituinte, ano 1, 1987a. Disponível em: <http://www2.camara.leg.br/>. Acesso em: 27 jun. 2018.

. Resolução no 2, Diário da Assembleia Nacional Constituinte, vol. 33, p. 871-884, $1987 \mathrm{~b}$. Disponível em: <http://www2.camara.leg.br/>. Acesso em: 27 jun. 2018.

. Atas da Assembleia Nacional Constituinte, Diário da Assembleia Nacional Constituinte, ano 1, 1988a. Disponível em: <http://www2.camara.leg.br/>. Acesso em: 27 jun. 2018.

. Resolução no 3, Diário da Assembleia Nacional Constituinte, vol. 163, p. 6.277-6.278, 1988b. Disponível em: <http://www2.camara.leg.br/>. Acesso em: 27 jun. 2018.

ChAVEZ, R. B. The rule of law in nascent democracies: judicial politics in Argentina. Stanford University Press, 2004.

ELSTER, J. "Forces and mechanisms in the constitution-making process". Duke Law Review, vol. 45, no 2, p. 364-96, 1995.

Filgueiras, F. "Institutional development and public control: analyzing the Brazilian accountability system". Cuadernos de Gobierno y Administración Pública, vol. 5, no 1, p. 1-26, 2018.

FINKEL, J. S. Judicial reform as political insurance: Argentina, Peru, and Mexico. Notre Dame: University of Notre Dame Press, 2008.

Folha dE S. PAULO. "Fiscalização de estatais vai ser feita por sorteio", p. A 28, 29 jul. 1987.

. "TCU inicia 'blitz' para levantar os gastos das estatais", p. A 48, 9 ago. 1987.

FONSECA, T. N. "Nem indicação política, nem cooperação: a importância da autonomia do TCU no controle de recursos públicos federais transferidos aos municípios". Dados, vol. 62, no 3, 2019.

GinsbuRG, T. Judicial review in new democracies: constitutional courts in Asian cases. New York: Cambridge University Press, 2003.

Ginsburg, T.; Versteeg, M. "Why do countries adopt constitutional review?". The Journal of Law, Economics, \& Organization, vol. 30, n० 3, p. 587-622, 2014.

Gomes, S. "O impacto das regras de organização do processo legislativo no comportamento dos parlamentares: um estudo de caso da Assembleia Nacional Constituinte (1987-1988)". Dados, vol. 49, no 1, p. 193-224, 2006.

Hidalgo, F. D.; Canello, J.; Lima-De-Oliveira, R. "Can politicians police themselves? Natural experimental evidence from Brazil's audit courts". Comparative Political Studies, vol. 49, no 13, p. $1.739-1.773,2016$.

HIRSCHL, R. Towards juristocracy: the origins and consequences of the new constitutionalism. Cambridge: Harvard University Press, 2004. 
KNIGHT, J. Institutionalizing constitutional interpretation. In: FEREJOHN, J.; RAKOVE, J; RILEY, J (orgs.). Constitutional culture and democratic rule. New York: Cambridge University Press, 2001.

Koerner, A.; FreItAS, L. "O Supremo na Constituinte e a Constituinte no Supremo". Lua Nova, São Paulo, vol. 88, p. 141-184, 2013.

Loureiro, M. R.; Teixeira, M. A. C.; Moraes, T. C. "Democratização e reforma do Estado: o desenvolvimento institucional dos Tribunais de Contas no Brasil recente". Revista de Administração Pública, vol. 43, no. 4, p. 739-772, 2009.

LoUREIRO, M. R., et al. "Do controle interno ao controle social: a múltipla atuação da CGU na democracia brasileira". Cadernos Gestão Pública e Cidadania, vol. 17, no 60, p. 54-67, 2012.

MAGALONI, B. Enforcing the autocratic political order and the role of courts: the case of Mexico. In: GinsBURG, T.; MoustafA, T. (orgs.). Rule by law: the politics of courts in authoritarian regimes. New York: Cambridge University Press, 2008.

MAHONEY, J.; GoerTz, G. "A tale of two cultures: contrasting quantitative and qualitative research". Political Analysis, vol. 14, no 3, p. 227-249, 2006.

Melo, M.; Figueiredo, C. M.; Pereira, C. "Political and institutional checks on corruption: explaining the performance of Brazilian audit institutions". Comparative Political Studies, vol. 42, no 9, 2009.

OLIVIERI, C. A lógica da política do controle interno: o monitoramento das políticas públicas no presidencialismo brasileiro. São Paulo: Annablume, 2010.

O Estado de S. Paulo. "O novo papel do TCU", p. 2, 7 jul. 1988.

RAMSEYER, J. M. "The puzzling (in)dependence of courts: a comparative approach". The Journal of Legal Studies, vol. 23, no 2, p. 721-747, 1994.

SANTISO, C. "Auditing for accountability: the political economy of government auditing and budget oversight in emerging economies". Tese de Doutorado. Johns Hopkins University, Maryland, 2007.

SCHLOSSER-BeRsCH, K.; TAYLOR, M.; PRAÇA, S. "State capacity, bureaucratic politicization, and corruption in the Brazilian state". Governance: An International Journal of Policy, Administration, and Institutions, vol. 30, p. 105-124, 2017.

Shapiro, M. The success of judicial review and democracy. In: Shapiro, M.; Stone-SweEt, A. On law, politics and judicialization. Oxford: Oxford University Press, 2002.

SPECK, B. W. Inovação e rotina no Tribunal de Contas da União. São Paulo: Konrad Adenauer Stifung, 2000.

Auditing institutions. In: POWER, T.; TAYLOR, M. (orgs.). Corruption and democracy in Brazil: the struggle for accountability. Notre Dame: University of Notre Dame Press, p. 127-161, 2011.

STEPHENSON, M. C. "'When the devil turns...': The political foundations of independent judicial review". The Journal of Legal Studies, vol. 32, no 1, p. 59-89, 2003.

SWEET, A. S. Governing with judges: constitutional politics in Europe. Oxford: Oxford University Press, 2000.

TAYLOR, M. M.; BURANELLI, V. "Ending up in pizza: accountability as a problem of institutional arrangement in Brazil". Latin American Politics and Society, vol. 49, nº 1, p. 59-87, 2007. 
TeiXeirA, M. A. C. "Tribunal de Contas da União - Trajetória institucional e desafios contemporâneos. Estado, instituições e democracia: República". Projeto Perspectivas do Desenvolvimento Brasileiro Ipea, vol. 1, no 9, p. 415-441, 2010.

TeiXeira, M. A. C; Alves, M. A. "Ethos organizacional e controle da corrupção: o TCU sob uma ótica organizacional". Cadernos Adenauer, vol. 12, no 3, p. 75-97, 2011.

VAN EVERA, S. Guide to methods for students of political science. Ithaca (NY): Cornell University Press, 1997.

\begin{abstract}
Between risks and threats: independence and oversight power of the Brazilian Federal Audit Court in the 1988 Constituent Assembly

Why would political actors take the risk of being controlled in the future by independent anticorruption institutions? The paper intends to explain what motivates politicians to give independence and power to these institutions, even they are under the risk of being controlled in the future. With the process tracing method, this paper gathers evidence regarding the institutional design of the Brazilian Federal Audit Court that was approved during the Constituent Assembly in 1988. The result shows that, regardless of the politicians' preferences, anti-corruption institutions purchase greater power through threats against the survival of political actors in contexts of future uncertainty. This diagnosis questions whether the independent anti-corruption institutions actually are an output of democratic competition, since these are not always a straight result from the majority preferences of elected representatives.
\end{abstract}

Keywords: accountability institutions; horizontal accountability; independent institutions, judicial review; corruption

\title{
Resumen
}

Entre riesgos y amenazas: independencia y poder de supervisión del Tribunal Federal de Auditoría de Brasil en la Asamblea Constituyente de 1988

¿Por qué los actores políticos se arriesgan a ser controlados en el futuro por instituciones anticorrupción independientes? El artículo tiene como objetivo explicar qué motiva a los políticos a dar a estas instituciones una mayor independencia y poder a riesgo de ser controlados en el futuro. A través del método de rastreo del proceso, el artículo reúne evidencia sobre la aprobación del diseño institucional de la Corte Federal de Cuentas de Brasil en la Asamblea Constituyente de 1988. Los resultados indican que, independientemente de las preferencias de los políticos, las instituciones anticorrupción obtienen mayor poder a través de amenazas a la supervivencia política de los actores en contextos de incertidumbre futura. El diagnóstico cuestiona si las instituciones anticorrupción independientes son producto de disputas democráticas, ya que no siempre son el resultado directo de la preferencia mayoritaria de los representantes elegidos.

Palabras clave: instituciones de accountability; accountability horizontal; instituciones independientes, control constitucional; corrupción

\section{Résumé}

Entre risques et menaces: indépendance et pouvoir de contrôle de la Cour fédérale des comptes brésilienne dans l'Assemblée constituante de 1988

Pourquoi les acteurs politiques risqueraient-ils à l'avenir d'être contrôlés par des institutions anticorruption indépendantes? L'article vise à expliquer ce qui motive les politiciens à donner à ces institutions plus d'indépendance et de pouvoir, au risque d'être contrôlées à l'avenir. Grâce à la méthode process tracing, l'article systématise les preuves concernant l'approbation de la conception institutionnelle de la Cour fédérale des comptes dans le Processus Constitutif de 1988. Les résultats indiquent que, quelles que soient les préférences des politiciens, les institutions anti-corruption 
acquièrent plus de pouvoir grâce à menaces à la survie politique des acteurs dans des contextes d'incertitude future. Le diagnostic soulève des doutes quant à savoir si les institutions indépendantes de lutte contre la corruption sont le produit de conflits démocratiques, car elles ne sont pas toujours le résultat direct de la majoritaire des acteurs politiques.

Mots-clés: institutions de accountability; accountability horizontale; institutions indépendantes, contrôle constitutionnel; corruption

Artigo submetido à publicação em 19 de dezembro de 2018. Versão final aprovada em 22 de junho de 2020.

Opinião Pública adota a licença Creative Commons CC-BY. 